\title{
Yorùbá Values and the Environment
}

\author{
John Ayọtunde Ișọla Bẹwaji \\ Department of Language, Linguistics and Philosophy, \\ University of the West Indies, \\ Mona Campus, Jamaica \\ tunde.bewaji@gmail.com
}

\begin{abstract}
This essay deploys Yorùbá ontology, epistemology and axiology to construct a Yorùbá ecological philosophy, or ecosophy. It argues that in contrast with the Judeo-Christian tradition of environmental anthropomorphic domination as the destiny of humanity or American pragmatism which encourages no stable traditions of values but what conduces to desired ends, the Yorùbá value system is by far more advanced in being more eco-respecting, eco-friendly and geared toward sustainable human habitation in a world in which he/she constitutes one small fraction of sentience. The essay developed around the responses to the following questions: a) What are values? b) How are values derived? c) Are there Yorùbá values? d) What is the environment? e) How are concepts of the environment derived? f) What is the relationship between values and the environment? g) What is the relationship between Yorùbá values and the environment? $h$ ) What are the inferences these have for one-health approach to the environment and sustainable human global co-existence?
\end{abstract}

Keywords: Ecosophy, Values, Anthropomorphism, One-health approach, Environment 


\section{Introduction}

Yorùbá civilization is one of the most ancient, advanced, and urbanized in the world. Various forms of evidence have demonstrated this. Among these sources are the archaeological, anthropological, socio-politico-cultural engineering, leisure and entertainment engagements, linguistic-communal organizations, highly articulate and well-formulated epistemological, scientific and mathematical traditions, technological and pharmacological traditions, ontological and axiological traditions and the values that feed, nurture and derive from these accoutrements of highly advanced culture (Zaslavsky 1999). Because Yorùbá society is large, centralized in Western Nigeria, and diffused through various circumstances of dispersals and exigencies to other parts of Western and Central Africa, the Americas, and the Caribbean, it is well-nigh impossible to annotate a homogenous value system; it will be trite to say such a diverse and highly civilized people would not have a homogenous value system. Hence, an awareness of this danger of presumed unanimity signals a caveat, that as much as even a small community of humans may display individual value variations, when it comes to large segments of humanity, indicating a common value system or tradition becomes even more challenging.

Having made this point, however, it is still significant that regardless of whether each and every individual member of the community embraces a particular or divergent value orientation, it is still meaningful to speak of a "common" value system from which most critical issues are understood, meaning made, and decisions effected, given historio-genesis and ancestral antecedents of peoples of the world. Our interest in this discussion is the appreciation of the overarching Yorùbá value system(s) in the natural relationships which members of Yorùbá society display in interacting with their environment writ large, with "environment" here being construed as natural, social, political, moral, cultural, jurisprudential, religious, etc. (Shyllon 1987). In this essay, we will use Yorùbá ontology, epistemology, and axiology to evince a Yorùbá ecosophy. In the process we will show that, in contrast with the Judeo-Christian tradition of environmental anthropomorphic domination as the destiny of humanity or American pragmatism which encourages no stable traditions of values but what conduces to desired ends, the Yorùbá value system is by far more advanced in being more eco-respecting, eco-friendly, and geared toward sustainable human habitation in a world in which he/she constitutes one small fraction of sentience. Our discussion will be developed as responses to the following questions: a) What are values? b) How are values derived? c) Are there Yorùbá values? d) What is the environment? e) How are concepts of the environment derived? f) What is the relationship between values and the environment? g) What is the relationship between Yorùbá values 
and the environment? and h) What inferences do these have for one health approach to the environment and sustainable human global co-existence?

\section{Values}

In virtue of human gregariousness, physiological, psychological, and intellectual dispositions, it can be argued that values under-guard virtually all aspects of human existence. Interactions and modes of being are moderated by ideas, beliefs, suppositions, and expectations that are steeped in, and that create, notions of values. Values evolve in various ways, consciously or otherwise, to authenticate the processes of being. One may also contend that it is not just human beings who evolve values, but other primates or animals in nature, with the capacity for feeling and emotion, memory, and history, reason and intellectual traditions also develop value-like notions, which they find various ingenious ways to orchestrate and defend. What, then, are values?

The concept of "value", on its face, derives from human appreciation of worth, importance, or utility of some/thing, where "something" or "thing" could stand for a being, an idea, a material or resource, a location, etc. To this end, "value" could be the concept used to describe those attributes, helping to annotate the regard the item deserves. To have value in the above sense is to be important, to be of worth and to be useful. But that is not all: to have value also could mean to be numerable, with potential for the quantity to have significance statistically, demographically, chronologically, symbolically, contextually, substantively or expressively. It may also mean the principles, ideologies, or standards by which one and one's society/community lives, relates to others, makes decisions, or determines modes of existence. But "value" could also mean substitution cost or exchange equivalence or benefit derivable from a substance, item, or idea.

From these ideas it would seem clear that values suffuse and are integral to all aspects of existence and moderate inter and intra relationships between humans, animals, nature, and the uni/multiverse. They become refined and reified over time, thereby assisting in determining the modes of being which members of different societies exhibit. Values also tend to take on autonomous lives, as these require such independence to gain the kinds of traction that allow for various mechanisms of adjudication-praise, blame, reward, punishment, etc. These elements of values are manifested in the critical areas of decision making-for example, a culture built on the idea of divine providence-but often are obscured by the fact that in many instances the values are not explicitly formulated, humans may be too busy just living/surviving to have enough time to examine the metaphysical presuppositions that underlie the ways of being that make a people who they are. 
Critical academic reflections about values belong in the area of philosophy called axiology, but the practical implications of the application of values often make urgent decision-making considerations to have a tendency to supersede theoretical constructions. For example, while pragmatism is a philosophy of being in the United States-no better evidence of this than the Trump regime in the White House-it is also a metaphysics of values, a mode of understanding the foundations of existence and construction of reality. Saying that philosophy considers value does not mean that other intellectual disciplines do not do so; for, the reason why these different areas command study is because they have enshrined in them cognitive or epistemic ideas, which are of interest to human beings intrinsically or instrumentally. To this end one can say that the humanities-including the social sciences, as well as the natural and applied sciences-are aimed at discovering intellectual secrets of nature, the environment, and reality. To this end, all human societies have made efforts to gain ideas, information, and knowledge regarding all aspects of existence. Life is the first area of value that humans have examined, but in doing this it has become clear that knowledge is probably the second most important of values that human beings have discovered.

\section{Sources of Values}

Circumstances of existence or coming about of societies differ, both in the environment of existence and contexts of survival. This means that different cultural handlers, as values, evolve and subsist to deal with exigencies of being. Apart from life and knowledge, humans value stability, and hence seek to enshrine values aimed at creating and maintaining standards of evaluation, which are conducive to the preservation of life in as best condition as possible, using the value of knowledge as tool. This translates into another value trope: power. Now, it must not be supposed that "power" means the ability to compel, force, subject, act upon, produce an effect, or influence that one thing/ being may have over other things/being. It may also manifest in the capacity to determine what individuals or groups have the freedom to even contemplate as truth, reality, or identity-as where some people decide their God is the real God and all other gods are fake, their educational system is genuine, while others are backward or unscientific (Gordon and Gordon 1997). Thus, "power" is valued intrinsically and extrinsically. To this end, it can be seen that values guide purposeful action, making human behavior superior, in many respects, to the behavior of other sentient beings in the world.

Value determines conditions of being and non-being, determining relationships as well as goal and processes. Values determine how we see what we see, what actions are worthy and how these are to be pursued. This is where 
historical factors play important roles in the engineering of values in society. The engineered values are then regarded as cultures: they are enshrined in the stories, theories, technologies, arts, educational systems, religious practices, patterns of relations (economic, political, filial, relaxation, sexual orientations) and numerous others for making peace, war, conflict management, etc. These values then assist in underwriting what society considers important to preserve, perpetuate by propagation or jettison by rejection or destruction.

The challenge of post-modern society is the Nietzschean/Trumpian trans-valuation of values - the seeming demise of human capacity to make meaning and have ideals, notions of right and wrong, good and evil, beauty and ugliness, proper and improper conjugal relations, etc. This is the element of fluidity that afflicts contemporary post-modern humanity in the face of scientific, technological, and globalization successes, making at the same time for the possibility of prolonging life on the individual level and destroying it wantonly at the mass level that has not been seen before. In a sense, what has happened to global humanity has been the capacity of segments of humanity to determine what would constitute values, not just for themselves, but for the rest of humanity. The historicizing of such capacities, through exclusionary narratives of exceptionalism, have meant that not just religious, but also ideological values are foisted on others either through the force of arms or a combination of educational and religious indoctrination. The factors of epistemicide and epistemic deficit in Africana societies have had the consequence of breeding a generation of Africans who doubt whether their ancestors ever had any values or capacities for such abstract constructs (Bewaji 2012). It has led to the Black Skin, White Mask (Fanon 1967) or double consciousness (Du Bois 1990) that plagues the African intellect and daily existence. The indignities that this has brought have been compounded by the double assault of poverty and ignorance of traditions to create the leverage for the destruction of indigenous knowledge systems in favor of pernicious imported fads and consumer items.

While it may be difficult to recoup or excavate old values, traditions, and beliefs, there is nothing stopping us from at least recognizing what was, evaluating it, and determining whether there is still any place in our existential circumstances to enable us to gain some benefits from the knowledge and possibly even from some modified application of those values, ideas and beliefs. It is this that has often encouraged my determination to never stop reflecting on and interrogating indigenous Yorùbá or African knowledge and metaphysical systems, even while detractors would ignorantly suggest that there is no such thing as Yorùbá values or knowledge; forgetting that it is only a difference of metaphor that prevents them from seeing that all knowledge is geo-culturally produced, deployed in a utilitarian fashion for other-possession 
or dispossession and metaphysically appropriated to mask the true purposes of such determination.

\section{Sources of Yorùbá Values}

The Western narrative of the origin of the universe is derived from an anthropocentric narrative found in Judeo-Christian scripture. It is found in the Book of Genesis, in the first four chapters. ${ }^{1}$ There the absoluteness of Yahweh is beyond reproach, creating the uni/multiverse by fiat of the spoken word and enthroning human beings as the master (masculine gender specifically) of all that there is in the universe. Within this narrative, the female was an afterthought, a product of Adam's depression and lonesomeness. There may never have been any female had Adam been comfortable with himself-personally, mentally, emotionally, sexually, etc.

Now, this mythological fiat persists in various forms, but most virulently in individualism, which now masquerades as democratic capitalism; the attendant contradictions it purveys are the rationale for the fundamental retreat and decadence of Western morality and value system. For this reason, the Western value system must be apprehended through the metaphysics of individualism (especially the possessive, destructive, obsessive, recessive, and patently amoral form of individualism), which seeks the domination and destruction (to the point of mass killing of fellow human beings being described as collateral damage and of no serious consequence in the prosecution of desired self-enrichment goals of the capitalist) of nature and others, carrying in tow the degenerate embers of patriarchy and cultural immolation. This also explains how it is possible to distance moral discourse from real life existence, fashioning narratives which brook no ideas of permanence, responsibility, or virtue.

There can be no doubt that when this narrative was introduced to Yorùbá society, Yorùbá people would have been amazed that there are people who call themselves humans who embrace such values. But Yorùbá wisdom is tolerant, being a product of millennia of cosmopolitanism and advanced cultural engineering, which have produced the kinds of urbanization which visitors marveled at on first contact (Bewaji 2016). Granting the strange, unknown and remote the latitude to demonstrate, through practical actions and behavior, their own humanity, the Yorùbá , in sympathy with their European weather

1 The Hebrew Bible is a collection of texts or scriptures considered by believers to be sacred, and that Jews and Christians consider to be a product of divine inspiration and a record of the relationship between God and humans, written by various individuals over an extended period of time, spanning many generations. Curiously, the Bible that has come down was a product of selection by some group of men, and hence cannot be considered exhaustive of such divinely inspired writings but the fiat of some privileged few. 
beaten, emaciated and clearly sickly-looking brothers and sisters, allowed them to visit, trade, learn and be civilized by the wealth of knowledge that was already part of the common fare in Yorùbáland. Probably this civilizational superiority was what conduced to the genteel accommodating manner of response to strange Western ideas, but which later resulted in the abuse of the generosity and humanity of the Yorùbá at the hands of the greedy white man, who reciprocated generosity with hostility, enslavement, and colonization.

One may wonder "how so?" Yorùbá creation ideas never arrogated to any Supreme Being, Eléduà, Olódùmarè or Olórun—or any other being—such contradictory, irreconcilable, and patently meaningless attributes. The structure of the cosmos, the uni/multiverse, and all that exists within it, was a product of not just one action carried out by one Supreme Being or beings, for obvious reasons. For someone to have carried out this process would have begged the questions: where was that being to begin the creation process? What was it/he/she made of? What language was used to create the uni/multiverse by fiat? How many such creations were undertaken, given the flawed experience of the biblical Garden of Eden? What image of God was usedBlack, Chinese, Indian, Latino, White? Why didn't the creator anticipate the depression of Adam if it/he/she was all-knowing? Yorùbá civilization never claimed to be the one and only civilization on earth, which was confirmed even more by interactions with peoples from other, strange lands and climes - they know that "if you travel far enough, you will find a hunchbacked squirrel” (àirin jìnnà ni kò jẹ a rí abuké ọkẹéré).

In order to understand Yorùbá values, just like attempts to seriously understand the values of the United States, European values, Chinese values, or those of any other value system, one has to revisit, among others, the metaphysics/ontologies and epistemologies constructed by the people as explanations of reality, knowledge of reality, relationships, etc. That was the reason for which we revisited the Judeo-Christian foundations of Euro-American value foundations in order to be able to gain an appreciation of why, in my opinion, the Judeo-Christian, Arab-Islamic, Western humanity is constantly destructive, war mongering, and spiritually hollow. In terms of origins, for Yorùbá people, there are two prevalent traditions of how the world came to be and how Yorùbá people originated. According to Stride and Ifeka,

The traditional history of Oyo goes back to the founding of Ile-Ife, the primary dispersal centre of the Yoruba people. One tradition of origin is a mythical creation legend which intimates that the Yoruba were the original inhabitants of the Ife area. At the dawn of time, the world was a watery waste. On the orders of his father - the supreme god, Olórun - Oduduwa climbed down a chain from the sky. He brought with him a handful of 
earth, a cockerel and a palm nut. He scattered the earth upon the water and it formed land at Ile-Ife. The cockerel dug a hole in which Oduduwa planted the palm nut and up sprang a mighty tree with sixteen branches, each the ruling family of an early Yoruba state. To this day Oduduwa's chain is preserved among the sacred relics of the Yoruba (1971, 288-290).

There are various renditions of this story/myth of creation, where Òrìsànlá is substituted for Odùduwà: a rope is substituted for a chain, a pouchful for a handful of soil, and a pigeon for cockerel and the ubiquitous palm nut. But the constants are the agencies of Olódùmarè or Olórun, Òrìsànlá, or Odùduwà, a pigeon or cockerel, a palm nut, blending Divinity with deity/god/humanity, "lower" animals and plants in the process of creation, thereby providing a representation of all that is: supra-terrestrial, terrestrial, humans, animals, plants, and things. The significance of the multiagency collaboration in the creation (ní igbà iwásè) of what there is, will only become evident when we examine the nature of values in Yorùbá culture and how this determines relationships between supernatural beings, human beings, and all other things in nature.

According to Stride and Ifeka, Yorùbá people also have another story, a migratory one, depicting their understanding that they originated from somewhere:

Another tradition indicates that the Yoruba people were produced by inter-marriage between a small band of invaders from the savanna and the indigenous inhabitants of the forest. The story is that Oduduwa was the son of Lamurudu, sometimes described as a ruler from the East, sometimes as a prince of Mecca. When Islam was introduced into his homeland, Oduduwa refused to forsake the religion of his ancestors and he and his supporters were expelled from their native land. After long wanderings, they settled among the forest people and founded the state of Ife. Oduduwa had seven descendants. Some traditions say they were his sons; others call them grandsons. These seven young men moved out to found the ruling families in seven new Yoruba states. These were named as Òwu, Sábe, Pópó, Benin, İlá, Kétu and Ọyọ́ (ibid, 290).

Clearly, these myths of origin are also rich in culture, civilization, humanity and values. They indicate a people who, even in the face of colonization and cultural emasculation, still value their indigenous culture, and who are not reticent to embracing new ideas from others, but who abhor being compelled to accept orthodoxies that are incomprehensible, internally incoherent, or patently absurd-they would characterize Islam as imọlelimọ líle (literally, hard knowledge), and various Christian denominations such as Baptist, 
Methodist, Catholic, Pentecostal Christ Apostolic, and Celestial churches as ijo onítẹbomi, ijo elétò, ijo àgùdà, ijo alákatakití, and ijo gbárayílè, respectively. Regardless of our author's mischaracterizing the stories as legends, by comparison with how Judeo-Christian education has taught its adherents to see Genesis in the Jewish Bible in literal terms and divine larceny of land of siblings as ordained, there is no doubt that the Yorùbá explanation of origin of what there is is suffused with clear presuppositions regarding a well-articulated, meaningful, and coherent worldview, espousing meaning of life and existence, sophisticated value systems, intellectually robust ontologies, and epistemologies. Viewed as such, we find that all aspects of Yorùbá existence, as individuals, in communities, within groups, relationally to the cosmos and even in the structuring of otherness, are governed by higher order rules which make the kind of existential angst celebrated by dysfunctional philosophies in the West incomprehensible to the urbane, highly cultured, and axiologically tethered Yorùbá adult. How would apprehending your place as a male, female, young or old, rich or poor, clergy or laity, become a challenge, except in an environment of extreme, destructive, and incoherent individualism, which breeds pernicious greed, value negation, and pursuit of crass pleasure as an end-in-itself, as if people were hogs.

We will return to a proper attenuation of the relationship between Yorùbá conception of reality as the harbinger of a rich value system, which ensures the proper relationship to reality, be it social, material, intellectual, environmental, or spiritual. For now, we will explore the other element of our discussion-the environment-before linking both to make our point that for sustainable preservation of the environment to ensue, there is the need to revisit and adapt indigenous traditions of Yorùbá values.

\section{The Environment}

The common orthodoxy of Western education teaches that the "environment" is the totality of everything that is around us. In this conception, there is a distinction made between what is characterized by a false polarity as "living" and "non-living" beings. Strangely, this conception of environment only looks at the material aspect of the universe, as elements in what we humans are able to see, access and control for use toward our immediate and future gratification. These are physical, chemical, and other natural resources and forces. Those that are classified as living beings are the only beings that "live" in their environment. The reason for that is that they are in constant sensory interaction with their environment, often consciously and unconsciously adapting to conditions in their environment. Those classified as non-living are incapable of agency, sensation, or reason, according to the warped Western 
intellectual tradition. This remarkably false and meaningless bifurcation of beings into living and non-living enables humans, in this tradition, to privilege human beings and render, in rank anthropomorphic terms, the narrative of existences in purely utilitarian and instrumental terms. The extent to which living beings are able to derive benefits from non-living beings in their different interaction tropes between animals, plants, soil, water, and other living and non-living beings, it is to that extent that these others are to be valued.

It may be noticed here that we have been deliberately careful not to use "things" to describe any aspect of what there is in the uni/multiverse. The simple reason for that is the need to avoid the odious derogatory implications of categorizing beings as "things," as if not being an animal or a plant means being lifeless/useless unless, desired/demanded by human, on the one hand; and on the other hand, the implied devaluation of their essence and nature, which allow human beings to feel no compunction in disposing of them without consideration, until recently; for now humans in the West are beginning to appreciate the overall implications of their/human actions measured in terms of conduciveness to cosmic sustainability and, more critically, human survival within the environment in which we find ourselves. For this reason, it is best to look at the holistic way in which the Yorùbá creation narratives factor in all elements of reality to understand human relationships with each other, as well as with every being in the uni/multiverse, and the attendant values derivable from these ontologies and epistemologies. In Yorùbá culture, the environment-gbogbo ohun tí ó n' be la"yé àti àjulé ọrun ("everything that exists in heaven and on earth") - must be understood as the aggregate of surrounding beings, things, conditions, or influences. This also includes the totality of the ecosphere with all the various natural resources, the air, the minerals, the organisms, as well as the non-natural aspects emanating from our relations with each other in social, cultural and other ways, to shape our relations with nature, all material beings and non-material beings.

Extant Yorùbá literature of all genre, written and oral, performance or otherwise, point to the "environment" being seen in this all-encompassing way. The way Yorùbá narrative of origins indicate that the world was created through many agencies: the agency of Olódùmarè, the Supreme Being, those of the divinities, those of the animals, the contribution of the plants and all things in nature; the way in which indigenous knowledge systems are generated; the position of all categories of humans-young, old, women, men, leaders, followers, abled, challenged, etc., all conduce to a systemic appreciation of what constitutes the well-being of all beings. This is encapsulated in various didactic lessons for all, which the stories about Ijapá ti'róko’ ọko Yannibo (Tortoise, the husband of Yańnibo) regal young children in moonlit evening entertainment (Babalola, 1972). It is not possible to conceive of any aspect of 
reality in singular terms, where the nature, the identity, the destiny of any one of them does not coalesce into the constitutive categories that empower each one. Let us see these concepts presented in Yorùbá understanding of nature, the environment, reality, and essence.

When it is said that Òrìsànlá/Ộrúnmilà or Odùduwà descended from the sky to carry out the instruction of Olódùmarè to create the universe and all in it, the rope that supposedly brought him down has significance. If the rope had not played its part effectively and had been broken in the process of the descent, then there would have been chaos. For this, it is said that bi itakun o bá já, owọo ko ni te ọkéré l'óko ("if the rope is not broken, there is no way the squirrel can be captured/killed in the bush"). It is also said that adiye ba l'ókun, ara o ro'kun ara o ro adiye ("the fowl is perched on the rope, there is no peace for the rope, there is no peace for the fowl"). In essence, it is the maintenance of the equilibrium in all circumstances, with each being performing as expected, that will ultimately conduce to peace and harmony. When any aspect of reality is dislocated, for whatever reason, unless redress is achieved, by whatever means indicated, then the dislocation will affect all aspects of reality.

In the various stories about the tortoise (ijàpá), the stalking folk hero animal of Yorùbá mythology, it is clear that the values of respect, diligence, accountability, truthfulness, honesty, devotion, loyalty, etc., are never below the surface in all aspects of human endeavors and interactions with others and with non-person others. And when it comes to ideas about knowledge, belief, truth and meaning, it is clear that Yorùbá respect all humans, because no one can pre-empt the cognitive ability of any being unless given the opportunity to use what they know. In D. O. Fágúnwa's novels, these are amply demonstrated. Whether in the tale of İrèké-Oníbùdó (1965), Àdì itú Olódumarè (1964), İrinkèrindò Nínú Igbó Elégbè je (1961), or Ògbó jú Ode Nínú Igbó Irunmale (1950), there is the clear interlocking connection between all aspects of reality and the manner in which the values that Yorùbá profess are enunciated. The various scriptural texts on Ifá by Wande Abimbola $(1976,1983)$ and E. M. Lijadu (1972), Esu by Ade Dopamu (1986), Àwon Oríki Orílè, Àkó jopọ A lọ I I jạpá by Adeboye Babalọlá $(1967,1973)$, Ayé Ye Wọ́n Tán by Akínwumí İsọlá (2009) and other authors also attest to this element of Yorùbá understanding of reality, and the values these frame and enjoin. And the Yorùbá epistemological stance is respectful of all perspectives, be it from the young, the adult, the old, male, female, even the mentally challenged. The Yorùbá say, for instance, așiwerè l'ọ jọ tirẹ (even the insane has his or her own utility).

Remarkably, also, the dichotomy between realms of being that suffused the Western paradigm of polarities does not exist within Yorùbá cognitive and metaphysical consciousness, and even more especially such false bifurcation is absent in Yorùbá value system. This does not mean that Yorùbá does 
not separate good from bad, or right from wrong; it is the understanding that there is a continuum of natural and unnatural relationships which mean that the movement of things from one domain to the other is never as absolute as many may think. It is for this reason that the creation story of descent on a rope from the sky/heaven does not seem paradoxical. And in Ile-Ife, there is the belief that there is a spot you can actually go to to travel to the world beyond. The story of Òrúnmilà and his movement between heaven and earth is a clear example of this.

What is even more interesting is the fact that Yorùbá people believe that all animals have their own traditions, languages, histories, and natures. These are what make them distinct in their different species, and these also ensure their capacity for survival as distinct beings. If humans were able to listen to the voices of animals and other beings in nature, we would be surprised by the kinds of discourses that take place between them. It may be that even the ethnic/racial divides between human groups are non-existent among animal species; and the same may be true of plants, rocks, rivers, seas, etc. Maybe this explains why streams like to flow into rivers, rivers like to flow into seas and seas like to flow into oceans. Maybe this is why the earth is round and everything relates to everything, and the going constitute the coming, while the dying constitute the coming into being. It is even possible that this accounts for the understanding of aberrant behavior and choices for what they are digbolugi, a "thuggish" type of lifestyle.

\section{The Relationship between Values and the Environment}

The reason we started this discussion with the ideas of creation or origin of the universe in the Judeo-Christian tradition and mapped the Yorùbá ontological tradition was with a view to showing the direct nexus between cultural ontology/metaphysics and values. By the time we factor in the epistemological categories deriving from the Greeks and the modern European-perhaps the most backward segment of human intellectual history-as exemplified by Descartes and his res cogitans, the individualization of knowledge, without any foundation in the historical antecedents of the person, then we will begin to see how and what accounts for the destructive streak in Western humanity, in comparison with other cultural traditions, of which Yorùbá ontology is a remarkable example.

While it may seem that both Judeo-Christian and Yorùbá ontologies and metaphysics take as a given the existence of a Supreme Being (Yahweh for Jews and Olódùmarè for Yorùbá), the trajectories of cosmological fabrications are totally at variance. The one, Judeo-Christian tradition, places the magical creation effort on the person of the Supreme Being, with all the attendant 
difficulties arising from such saddling of the Being with the complexities of failure, imperfection, incapacity to monitor and issues relating to adjudication of right and wrong, regardless of the circumstances of action and inaction. The other, the Yorùbá tradition, understanding that it is incoherent and impossible for any being to so fashion and maintain a uni/multiverse of so much complexity, imbued divinities, human beings, and indeed all beings, with the responsibility of not just fashioning but ensuring the wholesome and sustainable survival of all aspects of existence. For this reason, it becomes clear that the Yorùbá metaphysics/ontology has within it the malleability and instructability required to ensure that Olódùmarè does not become a victim of His greatness, and that human beings never get so carried away as to forget that whatever they have received in trust for use, they must maintain in good condition for posterity.

If the creation of terra firma was a product of the agency of multiple entities-Olódùmarè instructing, Òrìsànlá/Odùduwà descending through a rope, pouch of earth, pigeon or cockerel, palm nut, etc., then the appreciation of process and product places a consciousness of value on all concerned not to take anything for granted. For this reason, there has to be the value of respect for the integrity of all that exist, past, present, and future. The creation of the human being is even more instructive. While in the Judeo-Christian Western tradition, Yahweh created human beings after creating all things, and giving it a soul, and pronouncing human beings master of all, user of all, without responsibility for anything, in the case of Yorùbá, a divinity makes the body, another the head, and the individual is responsible for the choices of good and bad, right and wrong that he/she originates. This makes it clear that humans are not passive receivers of bounty for which no responsibility ensues. On the contrary, the human being contributes to the state of the world, a world in which there is no perfection, either in the extra-terrestrial realm or in the terrestrial realm.

How is this so? After creating everything in six days and resting on the seventh, the Judeo-Christian Western God declared his work as perfect, good, and irreproachable! The intellectual incoherence of such a claim did not seem clear to this narrative, till shortly after it was found that the only soulAdam - who had been placed within the Garden of Eden was a picture of pity, misery, and depression. This led to the subsequent creation of Eve. Even then, the immediate problem of perfection leading to disobedience did not grate the intellectual sensibility of the Western narrative, as the Great Fall through the consumption of the forbidden fruit was itself predictable as it underscored the fallacy of perfection attributed to Yahweh. Now, this is not to even begin to mention the perfidy of Yahweh in designing a conflict-ridden future for his creation, through the idea of "the chosen race" and "the promised land." For, 
how would humanity live with the idea that a good and perfect, all-knowing and all-powerful being, created us all and chose one strand of that creation to take what belongs to all and expect that such divine larceny will go uncontested?

Just flip the coin once, and look at the Yorùbá narrative, which understands that there may even be times when the Supreme Being, Olódùmarè, may get befuddled with the affairs of his domain and need to consult the divinity charged with wisdom, Ờúnmilà, Baba Ifá, who traverses both the spaces of the divine as well as that of the material, using ọpẹlẹ and Ifá divination to assist gods and humans in navigating the variegated conundrums of existence. To show that charging any being with absolute wisdom, power and truth is ludicrous; the Yorùbá use the tortoise exploits of claiming to assemble all wisdom in a gourd, which he would try to carry to the top of a palm tree so that no one will be able to access it, except himself, but who did not even realize that the placement of the gourd on his belly will make climbing the palm tree well nigh impossible, until a passerby pointed this out to him. He changes the location, but still fails until another person pointed out that the location made his ascent impossible. The moral of the story is that no one can claim to know everything. This is even better reinforced in the belief that it is through the combination of the wisdom of all that Ile-Ife was founded (omodé gbọn, àgbà gbọnn, la fi șe isẹdálè Ifẹ).

Yorùbá values are deep and expansive, and recognize that certain things remain valid, even while everything continues to evolve. For example, human nature may indicate that certain activities and needs are constant, but there is recognition that how these needs are met and how the activities are carried out may vary. This is why they would say ayé n' yi lọ, à n' tọ ọ ("the world changes constantly, and we keep pace"). This not only speaks to the rotation and revolution of the earth around the sun, but also the evolution of how humans have to live in a changing, interconnected and shifting existential terrain.

We can hypothesize that there are hardly any aspects of human civilization where the values of community, society, and humanity of other societies do not appear superior to Western values. While the invaders of the Americas from Europe showed no interest in long-term survival of the so-called New World, such a system would have been totally deplored in Africa, where one has to be mindful of what happens tomorrow-a metaphor for an elastic and interminable future. For this reason, when you farm, you must allow the soil time to recover, through various clearly eco-friendly methods, compared with mechanized farming where the whole place is cleared, or where strange bio-organisms are introduced to boost production to maximize profit, regardless of consequences to self or to future generations. In governance, this 
is even starker. While the West celebrates "democracy" as a Greek heritage, it is very clear that there was nothing to celebrate about Greek democracy, because it was government of the few over the many, the so-called free born over the community of serfs, slaves, and women who had no voice in the agora. This tradition has persisted today, making for what one can describe as the democracy hubris, as Western democracy is not about the welfare of the people, but the entrenched interests of the rich, politically connected and those whose sole interest is using power and connections to feather their own nests at the expense of society.

Democracy has morphed into an expensive self-consuming monster in the West and in societies that have uncritically embraced the democracy hubris, taking large chunks of budgets to feed the industry of democracy, which resides in Western capitals. While the infrastructure and employment situation in Western "civilizations" are falling apart, funds must be found to carry out the regular charade of elections, with the sole purpose of giving the poor masses the illusion of participation in governance. Compare that with democracy in Yorùbáland, where all are equally important and make contributions through self and other representation. While it may, on the surface, look like monarchy, autocracy or other, the fact of the matter is that no king, chief, or leader in Yorùbáland could survive as a dictator. The Yorùbá believe that $a^{\prime} g$ bájọ owó, òhun la fi n' sọ aya' ("there is strength in numbers, since it is with bunched fingers that one could boldly strike the chest"). The common denominator here is a value system that does not allow for tyranny, as each individual has an intrinsic worth, even while being physically challenged.

There are also clear values relating to nature, all aspects of nature. In many communities, trees, rivers, caves, and other natural resources have assisted the communities to survive in the past. Some of these natural resources, which would have been described in Western scholarship and education as non-living things, have provided special nourishment in times of need, some have been places of shelter during wars or natural disaster, and some have been the fall-back resources when all else seemed lost. For this reason, all things in nature deserves respect, recognition, and attention, so that they can continue to be useful and sources of sustenance to future generations. When a herbalist goes to assemble leaves, roots and barks of trees, he ensures that the sun is up before doing so, or speaks to the plants to seek permission to take some in the aid of nature's interconnected assistance to each other. The untutored may think this is superstitious. But such an ignorant dismissal of the practice forgets that potency is heightened when the sun is up and photosynthesis takes place, or even, more significantly, that respecting the plant, animal, or river means ensuring the preservation of the species and the environment. 
The cognitive environment is not left out. Epistemic responsibility values the collective effort, memory and ownership of knowledge, ideas, technologies, etc. This is what makes the current practice of copyright and patents ludicrous, for, in many instances, Western multinationals go into various indigenous communities, appropriate the indigenous knowledge systems, patent them, and give nothing back to the communities whence such knowledge is derived. Even when you look at what is done in Western scholarship, where books, essays, and results of experiments are patented and owned individually, this bodes poorly for the community that made the discovery possible, as there is no regard or obligation owed by the individual protagonists of such knowledge. This has made it possible for the few to be enriched at the expense of the masses of the people through the manipulation of information, ideas, and knowledge. What is done at the individual level is also done at institutional, national, and racial levels. For example, this is the implication of prohibiting certain countries from developing weapons of mass destruction, while rogue states like the USA and Israel have these weapons and use them regularly.

\section{Yorùbá and the Value of the Environment}

Our exploration has revealed some fundamental differences in cultural intelligence of Yorùbá society by contrast with the narcissistic, self-destructive and incoherent Abrahamic Judeo-Christian Western and Islamic societies. These differences account for the manner in which the latter's socio-cultural reflections, even while parading as universal truths and scientific paradigms, continue to construct ontologies of greed, domination, and destruction; epistemologies of exclusion whereby only the elite few are imbued with capacity for knowledge and remain the beneficiaries of the results of human collective cognitive engagements, and the most pernicious axiologies of conflict with enormous potential for collective human omnicide.

In the Yorùbá cultural intelligence that we have explored, the question of agency is a universal one which pervades not just the domain of humans, but also animals, plants, and other entities in nature, including the streams, rivers, seas, oceans, wind, clouds, rainfall, sunlight, etc. Such a holistic reflective view of the uni/multiverse requires cognitive respect for all things, which in turn leads to care and attention to what is revealed through the agencies in entities environing our spaces. Thus, while Yorùbá culture celebrates wonder and inquisitiveness, encouraging evidence gathering efforts as means of gaining knowledge, there is no arrogation of intellectual supremacy of omniscience to any being, whether natural or supernatural; hence, Olódùmarè 
consults Òrúnmìlà, his diviner, when confused or in need of an understanding of events past, present, and future. According to Wande Abimbola,

According to the myths, there were occasions when, there being no physical barrier between heaven and earth at that time, Ifá was summoned by Olódùmarè (God Almighty) to heaven to use his great wisdom to solve problems for Him. Ifá finally returned to heaven in annoyance due to an insult given to him by one of his children. Shortly after this, the earth was thrown into great confusion. Famine and pestilence raged throughout the earth. So great was the calamity that the fertility cycle in human beings was disrupted. Aboyún kò bímọ;/Àgan kò tộwọ àlà bosùn (Pregnant women no longer delivered;/Barren women remained barren). $(1976,5)$

The supernatural has obligations of respect and responsibility, and the natural has obligations of attention and respect toward that which not only makes life happy but also meaningful.

Hence, it is not strange for humans to learn from things around us; as humans observe the habits and behavior of animals, plants, and things in nature to gain insights into the use, tendencies, and the beauty of everything. Such a cognitive attentiveness and respect cannot lead to arrogance, nor does it translate into the appropriation of the intuitive beings of things that do not speak our language or that seem to be of lower rank. This is because if everything were to be uniform, the world would have been impossible to live in, and things would not have had all the systemic interdependence which make for the working of everything together for good and ill. It is in this sense that the good has its own inner capacity to become ill, and the ill, if only the patience to learn from nature to use the insights to correct and make amends, the inner capacity to yield good.

These insights have only just come to light in the West, but it is an uphill battle because of the cultural baggage of the West toward domination, destruction, and disrespect. So, when in recent years Western science begins to realize what older civilizations of Africa, China, and other Far Eastern societies always knew, the resistance has been pronounced, to the extent that there have been concerted efforts by the capitalist controllers of world resources and wealth to maintain the status quo of enriching the top wealthy few to regard global warming as a hoax. Those ignorant few, who are powerful and control the global wealth, and who believe that they can just continue to take without giving back to nature and to others, without responsibility for the survival of the species, continue to utilize their powers to the disadvantage of our collective survival. 


\section{One Health Approach to Environment and Sustainable Species Survival}

When Europeans first came to Yorùbáland, the narrative claims that they were received as distant members of the family and accorded deserved hospitality which such travellers, albeit inveterate wanderers, had suffered. They were not mistreated, because they were members of our human family. In any case, all sentient beings deserve respect; this even more so with persons who are our distant family members, regardless of the fact that we do not understand their tongues or ways of life. The reasoning is that if animals, plants, and things in nature are accorded respect as part of our world, how much less the persons who are very much like us, but who have suffered some terrible mishap in the course of their wandering. Compare this attitude with the Judeo-Christian tradition, which, through the bogeys of "the chosen race" and "the promised land" willfully concoct narratives of dispossession and expropriation of family members: Jews are Arabs, by their own scriptural account. When Europeans admitted to being inheritors of Greek intellectual traditions, and in virtue of that, the Christian tradition that followed the Roman Empire, it followed that it inherited the philosophy of dispossession and enslavement of others that comes with that tradition. When we compare this with the Yorùbá tradition, we see the stark differences.

When Yorùbá people say that eni tẹ etí aṣo rẹ mọ́lẹ̀, a fa t'ẹni ya, it means that "one who drags his/her own cloth/dress in the mud, will definitely rend another person's cloth/dress." What we get from this is a metaphysics, epistemology, and axiology of exceptionalism, superiority complex, greed, disrespect, and destruction. How so? Now, when one person appropriates, grabs and steals what is common property, and in the process commits genocide (i.e. Saul and the Amalekites) against kinsmen and women, then it is obvious that such a person will treat animals, plants, trees, rivers, and all other things in the environment worse. If by cultural intelligence, native appreciation of reality and intellectual effort, you are able to construct otherness in such destructive ways regarding other human beings who speak the same language as you, then it is clear that when confronted with a choice regarding those whose language you do not understand, your capacity for hospitality, empathy and charity becomes naught. This is not an accident then that when confronted with persons who are not only different looking, speaking languages different from theirs, it is easy to enslave, colonize, destroy and vanquish. This was what happened in the Americas with the deliberate extermination of the native populations by Europeans, followed by the most callous slavery ever invented (similar though to what existed in Greece, the cradle of Western democracy), and by extension the worst forms of colonialism and 
neo-colonialism in contemporary memory. In Yorùbá society there are records of strangers, foreigners, serfs, "slaves," and poor people who have risen to positions of prominence and leadership, intermarrying with the people without any prejudice. This is what is meant when it is said that $b i^{\prime} e w e$ ' $b a^{\prime}$ pé l'ára ọse, á di oṣe ("when the leaves stays too long on the soap, it becomes a soap eventually"). For the Yorùbá, what determines one's station in life is one's character, hard work and respect. The obverse is that one may be born to royalty, yet become poor as a consequence of laziness, bad character, or disrespect.

The ultimate goal of life in Yorùbá society is that of mutual survival. When you tap the palm tree for wine, you do it respectfully without cutting the shoot, even though it would have brought you more juice. And it is the height of abomination to uproot the palm tree, set fire to it at the bottom, to drain the juice from the top, even though what you get will be instantly more potent. These however are practices that exist in neighboring cultures, but the Yorùbá abhor them. When you fish, you do not catch the "children" or "babies" of the fish, and it is wrong to slaughter for delicacy the infant of the lamb or goat! When you farm, the prayer is that there be no hunger to make us eat both the yam and the seeds of the yam, or to start harvesting the yam before they mature. Such unnatural behaviors are regarded as "killing" the future of the various entities that surround us and which conduce to our welfare.

In the final analysis, the values which govern all aspects of existence are such that they come together to help promote the understanding that if those of us on the ground (ëpẹ) are not healthy, those that live in the air (birds) and in the sea (fishes) cannot be healthy. When examined carefully, the ontology of respect and empathy, protection of the weak and vulnerable, whether of humans, animals, plants, or other entities in our environment is predicated on the idea that our health is connected to the health of everything around us. Even morality of interpersonal relationships has much to do with the individual health, family health, community health, and global health.

\section{Conclusion}

The discussion in this essay has generated comparisons, which are rather unusual. Intellectual traditions are not the kinds of things that are brought to face off, especially not ontologies, epistemologies, and axiologies in the way we have done in this discussion. Some may not be comfortable with the ideas of suggesting that European values or Yorùbá values can be given cultural interpretation, rather than the values of individuals. But such hypocrisy will only mask the fact that cultures produce thinkers, who consciously and otherwise often become reflections of the cultures in their intellectual efforts, even when 
they pontificate from the rooftops that they are iconoclasts, irreverent. or revolutionary; you can only oppose what is possible in your imaginary.

When applied to Nigeria, we see a double bind brought about, on the one hand, by the effect of colonization and the amalgamation policy of 1914; and on the other hand, by the admixture of several incompatible ontologies, epistemologies, and axiologies that compete for attention within a state without direction. One consequence of this is that the national environment, held captive by capitalist orthodoxies, thereby fails to make sense of the issues that the Yorùbá clearly understand. Greed and personal aggrandizement have become clear national "virtues" that collude with global capitalist interests to undermine the collective health of the Nigerian state. A very distinct demonstration of this resides in the vast template of ecological denigration that we call the Niger Delta, which has become a metaphor for environmental irresponsibility. A deep dynamics of national greed has produced a fundamental ignorance about the fact that in dealing with plants, animals, and things in the environment, what one does today has serious repercussions for the future. Thus, if something is as useful today as the Niger Delta is as the golden goose that produces the oil wealth, it needs to be treated with the utmost respect and maintained in good health, so that it can continue to be relevant and useful in the future. A one-health approach, encapsulated in the Yorùbá ontology, epistemology, and axiology, possesses a sound possibility of enabling the reinvention of Nigeria's understanding of her natural and cultural environments

\section{Works Cited}

Abimbola, Wande. Awon Oju Odu Mereerindinlogun. Oxford: Oxford University Press, 1978.

Abimbola, Wande. Ijinle ohun enu Ifa 1. Glasgow, UK: Aim Press, 1968.

Abimbola, Wande. Ifa: an Exposition of Ifa Literary Corpus. Ibadan, Nigeria: Oxford University Press, 1976.

Abimbola, Wande. "Ifa as a body of knowledge and as an academic discipline." Journal of Cultures and Ideas, University of Ife, Ile-Ife, Nigeria, 1983. Pp. 1-11.

Abimbola, Wande. Ijinle ohun enu Ifa 2. Oxford: Oxford University Press, 1987.

Akiwowo, Akinsola. Ajobi and Ajogbe: Variations on the Theme of Sociation. Ile-Ife, Nigeria: University of Ife Press, 1983.

Babalola, Adeboye. Akojopo Alo Ijapa-Apa Kinni. Ibadan, Nigeria: O. U. P., 1973.

Babatunde, Adeboye. Akojopo Alo Ijapa-Apa Keji. Ibadan, Nigeria: O. U. P., 1973. 
Bewaji, John Ayotunde Isola, "Heritage, Cultural Preservation and Management" in Falola, Toyin and Akintunde Akinyemi (eds.). Encyclopedia of the Yoruba. 2016. Pp. 148-149.

Bewaji, John Ayotunde Isola. Narratives of Struggle - the Philosophy and Politics of Development. Durham, North Carolina: Carolina Academic Press. 2012

Dopamu, Peter. A. Esu: the Invisible Foe of Man. Ijebu-Ode, Nigeria: Shebiotimo Publications, 1986.

Du Bois, William Edward Burghardt The Soul of Black Folks. New York: Vintage Press, 1990.

Fagunwa. D. O. Ogboju Ode ninu Igbo Irunmale. Lagos, Nigeria: Nelson, 1950.

Fagunwa, D. O. Igbo Olodumare. Lagos, Nigeria: Nelson, 1949.

Fagunwa, D. O. Adiitu Olodumare. Lagos, Nigeria: Nelson, 1964.

Fagunwa, D. O. Irinkerindo Ninu Igbo Elegbeje. Lagos, Nigeria: Nelson, 1961.

Fagunwa, D. O. Ireke Onibudo. London: Nelson, 1965.

Fanon, Fanon. Black Skin White Masks. New York: Grove Weidenfeld, 1967.

Gordon, Lewis R. and J. A. Gordon. Not Only The Master's Tools. London: Paradigm Publishers, 1997.

Isola, Akinwunmi. Aye Ye Won Tan. Ibadan, Nigeria: DB Martos Press, 2009. Lijadu, E. M. Ifa. Ado-Ekiti, Nigeria: Omolayo Press, 1972.

Shyllon, Folarin. Freedom, Justice and the Due Process of Law. Nigeria, Ibadan: University of Ibadan, Inaugural Lecture 1986.

Stride, G. T. and Ifeka, Caroline. Peoples and Empires of West Africa. London: Nelson, 1971.

Zaslavsky, Claudia. Africa Counts: Number and Patterns in African Cultures. Chicago: Lawrence Hill Books, 1999. 